\title{
Developing and applying a benthic index of estuarine condition for the Virginian Biogeographic Province
}

\author{
John F. Paul ${ }^{\text {a,* }}$, K. John Scott ${ }^{\mathrm{b}}$, Daniel E. Campbell ${ }^{\mathrm{a}}$, John H. Gentile ${ }^{\mathrm{c}}$, \\ Charles S. Strobel $^{\mathrm{a}}$, Raymond M. Valente ${ }^{\mathrm{b}}$, Stephen B. Weisberg ${ }^{\mathrm{d}}$, \\ A.F. Holland ${ }^{\mathrm{e}}$, J. Ananda Ranasinghe ${ }^{\mathrm{d}}$ \\ ${ }^{a}$ US Environmental Protection Agency, 27 Tarzwell Drive, Narragansett, RI 02882, USA \\ b Science Applications International, Inc, Newport, RI 02840, USA \\ ${ }^{\mathrm{c}}$ Center for Marine \& Environmental Analyses, University of Miami, Miami, FL 33149, USA \\ ${ }^{\mathrm{d}}$ Southern California Coastal Water Research Project, Westminster, CA 92683, USA \\ e Marine Resources Research Institute, Charleston, SC 29412, USA
}

Received 17 September 2001; accepted 18 September 2001

\begin{abstract}
A benthic index of estuarine condition was constructed for the Virginian Biogeographic Province (from Cape Cod, Massachusetts, to the mouth of Chesapeake Bay, Virginia) with data collected during summers of 1990 through 1993 by the US EPA's Environmental Monitoring and Assessment Program (EMAP). Forty-eight metrics, based on attributes of the macrobenthos, were considered for the index, including measures of biodiversity, community condition, individual health, functional organization, and taxonomic composition. Salinity was correlated significantly with some of the metrics. Therefore, some metrics were normalized for salinity. The data used to develop the index (the calibration data) included equal numbers of reference and degraded sites, distributed equally across three salinity zones $(<5,5-18,>18 \%)$. An independent set of data was used for validation. Linear discriminant analysis identified combinations of metrics that could best discriminate reference from degraded sites. The targets for correct classification were $90 \%$ of the sites for the calibration data and $80 \%$ for the validation data. Six combinations of metrics were identified. The final index was based on the ecological interpretation and relevance of the individual metrics and the ability to meet the calibration and validation targets. The final index consisted of three metrics: a positive contribution from salinity-normalized Gleason's $D$ (a biodiversity metric), and negative contributions from two taxonomic composition metrics, abundances of spionid polychaetes and of salinity-normalized tubificid oligochaetes. The index correctly classified $87 \%$ of reference and $90 \%$ of degraded sites in the calibration data and $88 \%$ of reference and $81 \%$ of degraded sites in the validation data. The index correctly classified sites over the full range of salinity (tidal-fresh to marine waters) and across grain sizes (silt-clay to sand). ( 2001 Elsevier Science Ltd. All rights reserved.
\end{abstract}

Keywords: Macrobenthos; Benthic environment; Environmental conditions; Estuaries; Sediments; EMAP; Virginian Biogeographic Province

\section{Introduction}

Over the past decade, environmental monitoring

* Corresponding author. Tel.: +1-401-782-3037; fax: +1-401-782-3099.

E-mail address: paul.john@epa.gov (J.F. Paul). and assessment to address concerns of managers and the public has shifted from a narrow focus on chemical measures of condition to also include biological/ 
ecological measures and expanded in scale from local sites to regions (SAB, 1988; Hirsch et al., 1988; NRC, 1990; Messer et al., 1991; ITFM, 1992, 1995; CENR, 1997; Karr and Chu, 1999). These changes posed new challenges. Ecological measures of condition require metrics that respond to environmental stress. The large amount of information generated for characterizing biotic conditions calls for new techniques to synthesize and interpret the data. Broad geographic scales make it difficult to resolve the complexities of combining information from a diversity of habitats. One way of addressing these challenges is to use multimetric approaches that have been developed for combining environmental data into simple indices (Graca and Coimbro, 1998; Hartwell, 1998; Harris and Silveira, 1999) that make it easier for managers to use ecological data (Karr and Chu, 1999).

However, multimetric indices come with their own challenges. The users of such indices must (1) select the right mix of metrics by distilling the many possible choices to a small subset that reliably differentiates reference from degraded sites, and (2) ensure that the results are ecological plausible. The desired end result is an empirical index that is statisticallybased within an ecological context. Jackson et al. (2000), in their guidelines for evaluating ecological indicators, provide two examples for multimetric indices.

Macrobenthic communities are important parts of estuarine ecosystems (Rhoads et al., 1978; Pearson and Rosenberg, 1978; Sanders et al., 1980; Boesch and Rosenberg, 1981; Holland et al., 1987, 1988). Macrobenthic assemblages have been used to indicate stress because they are sensitive to pollution (Pearson and Rosenberg, 1978; Boesch and Rosenberg, 1981; Gesteira and Dauvin, 2000). These communities integrate the effects of pollutants and disturbances over the relatively long periods of months to years that are consistent with life-cycle attributes such as recruitment potential and longevity. Part of the reason why these community responses represent pollution so well is because benthic organisms live in sediments, which can accumulate contaminants over long periods (Schubel and Carter, 1984; Nixon et al., 1986). Another advantage of using benthic organisms, particularly infauna, is that their relative immobility hinders them from avoiding pollutants and other environmental disturbances in the short time.
Characteristics of macrobenthic communities, often expressed as indices, have been used for decades to measure and describe ecological status and trends of marine and estuarine environments (Sanders, 1956, 1960; Boesch, 1973; Pearson and Rosenberg, 1978; Holland et al., 1988; Engle et al., 1994; Weisberg et al., 1997; Adams et al., 1998; Gonzalez-Oreja and Saiz-Salinas, 1998; Angradi et al., 2001). This literature describes the attributes of macrobenthic communities that can be used to characterize ecological condition, including: (1) measures of biodiversity and species richness, (2) taxonomic composition, (3) biomass, (4) abundance or productivity of functional organization, and (5) abundance and/or productivity of "key" species (Weisberg et al., 1993).

This paper relates patterns in taxonomic structure and functional organization of the macrobenthos to stressors of interest while accounting for the large range of conditions in estuaries. Important stressors for the Virginian Biogeographic Province (Cape Cod to mouth of Chesapeake Bay) include hypoxia (low dissolved oxygen) in near-bottom waters and elevated contaminants in sediments. A successful analysis must account for the differential effects that these and other stressors may have on benthic organisms in the diverse habitats that range from freshwater to seawater and from silty to sandy sediments.

A benthic index of estuarine condition was originally developed using data from the 1990 Virginian Province Demonstration Project. The procedures used in developing this index were documented in Weisberg et al. (1993). The index was then updated using data from 1990 to 1991 (Schimmel et al., 1994). The index presented here has been developed from a subset of the data collected over the entire 4 years of sampling (1990-1993) in the Virginian Province (Strobel et al., 1995, 1999). It improves upon the previous indices, consistent with the stated intent to continually revise the index as new data become available (Weisberg et al., 1993). This benthic index of estuarine condition is applicable to the entire Virginian Province.

\section{Evolution of the benthic index for the Virginian Province}

The benthic index for the Virginian Province was developed by examining a wide range of possible 
metrics and using linear discriminant analysis (Cooley and Lohnes, 1971; Venables and Ripley, 1997) to select the combination that best discriminated reference and degraded sites. The general procedure involved the following four steps:

1. Identify a set of potential metrics that includes components of benthic community structure and function.

2. Identify two subsets of data, one for reference sites and another for sites degraded by toxic contaminants, hypoxia, or both.

3. Identify the combination of potential metrics that best discriminates reference and degraded sites.

4. Validate that combination with independent data.

The original calibration data were from the Virginian Province in 1990. They consisted of 19 degraded sites (4 with salinity $<5 \%$ ), which had low concentrations of near-bottom dissolved oxygen and/or sediments with high concentrations of contaminants and high toxicities, and 14 reference sites (six with salinity $<5 \%$ ), which were not hypoxic nor had contaminated or toxic sediments. The 1990 index correctly classified $89 \%$ of the degraded sites and $86 \%$ of the reference sites. Metrics included percent of the expected taxa richness (normalized to salinity), amphipod abundance, relative abundance of bivalves, mean weight of individual polychaetes, and abundance of capitellid polychaetes.

The 1990 index was validated with independent data to ensure that the multivariate solution was not restricted to the calibration data. The validation data were drawn from the 1991 data with the same selection criteria for reference and degraded sites used in 1990 (Schimmel et al., 1994). This validation set consisted of 46 reference sites and 13 degraded sites. The 1990 index correctly classified 39 of the 46 reference sites (85\%) and 7 of the 13 degraded sites (54\%). The high rate of misclassification for the degraded sites was unacceptable, and it was decided to construct a new benthic index from a subset of the combined 1990-1991 data.

This calibration data from 1990 to 1991 included 31 degraded sites (five with salinity $<5 \%$ ) and 51 reference sites (nine with salinity $<5 \%$ ), and led to a new index that correctly classified 85 and $84 \%$ of the reference and degraded sites, respectively. The index included metrics such as mean abundance of opportunistic species, biomass/abundance ratio for all species, and mean number of infaunal species. The index did not include metrics normalized for habitat;

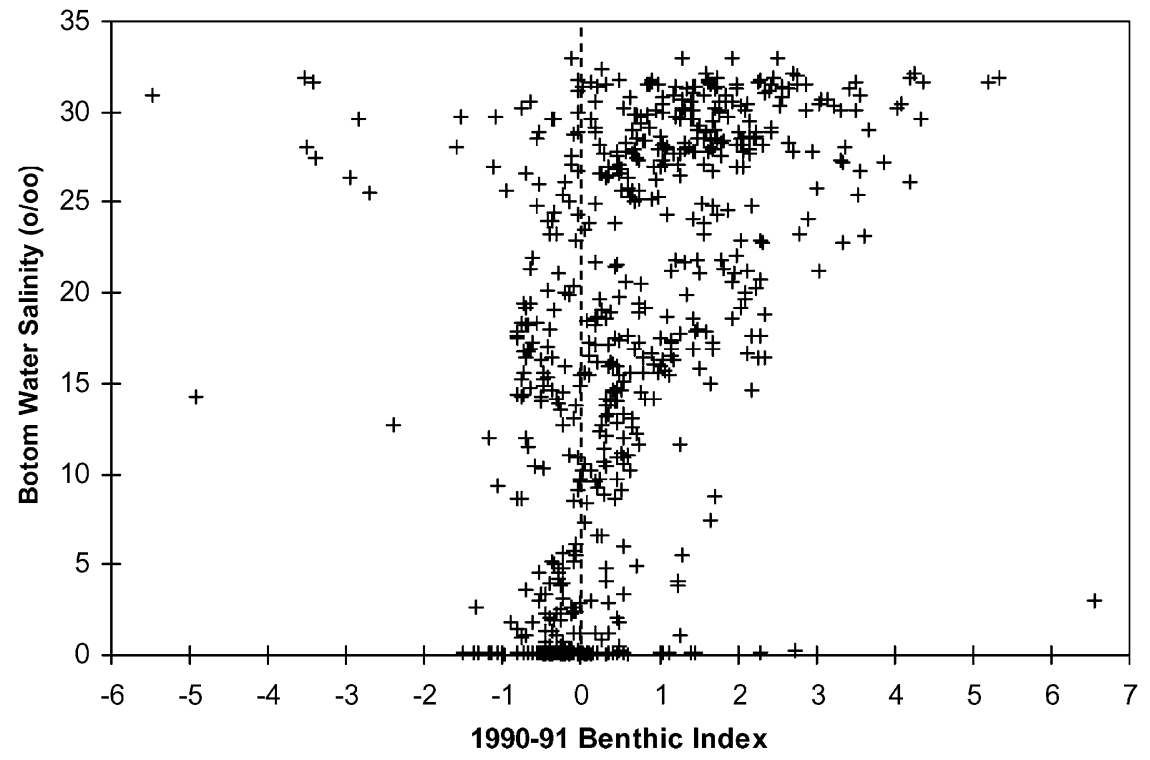

Fig. 1. The 1990-1991 benthic index vs. bottom water salinity for 1990-1993 EMAP Virginian Province data. Negative benthic index values indicate degraded conditions. 
normalizing factors such as salinity were considered, but were eliminated by the statistical analysis (see Schimmel et al., 1994, for details). Normalizing metrics for habitat accounts for the expected variation that occurs independent of the stressors. This 1990-1991 benthic index was developed with only five degraded sites in low-salinity waters $(<5 \%)$. When the 1990-1991 index was calculated for the entire 1990-1993 data set, benthic index values were correlated with salinity (Fig. $1 ; r=0.29, n=630$, and $P<10^{-6}$ ). It also appeared to misclassify good sites (benthic index $>0$ ) in freshwater/oligohaline waters $(<5 \%)$ and degraded sites in mesohaline and polyhaline waters ( $>5 \%$; Fig. 2 ).

Because of the salinity bias in the 1990-1991 index, it was reconstructed using 4 years of data (1990 1993) incorporating the following remedies (Paul et al., 1999):

1. some individual benthic metrics were normalized for habitat;

2. a wider selection of benthic metrics were included as candidates for the discriminant analysis;

3. the distribution of reference and degraded sites was balanced across salinity zones (equal number of sites per zone).
The same four basic steps used for the earlier indices were used for the 1990-1993 benthic index. This paper describes how this 1990-1993 index was developed and tested.

\section{Methods}

\subsection{Sources of data}

The data for the 1990-1993 benthic index came from samples collected in estuarine waters of the Virginian Province during July-August of 1990 through 1993. Vertical profiles of water-quality variables were collected at each station with a CTD equipped with probes for measuring salinity, temperature, depth, $\mathrm{pH}$, dissolved oxygen, light transmission, fluorescence, and photosynthetically active radiation.

Three benthic grab samples were collected at each station by using a stainless steel, Young-modified van Veen grab sampler that collects from a surface area of $440 \mathrm{~cm}^{2}$. Each sample was sieved through a $0.5 \mathrm{~mm}$ screen, preserved, and stored for later analysis. The organisms were identified and counted, and the biomass was measured. Biomass was determined as shell-free dry weight.

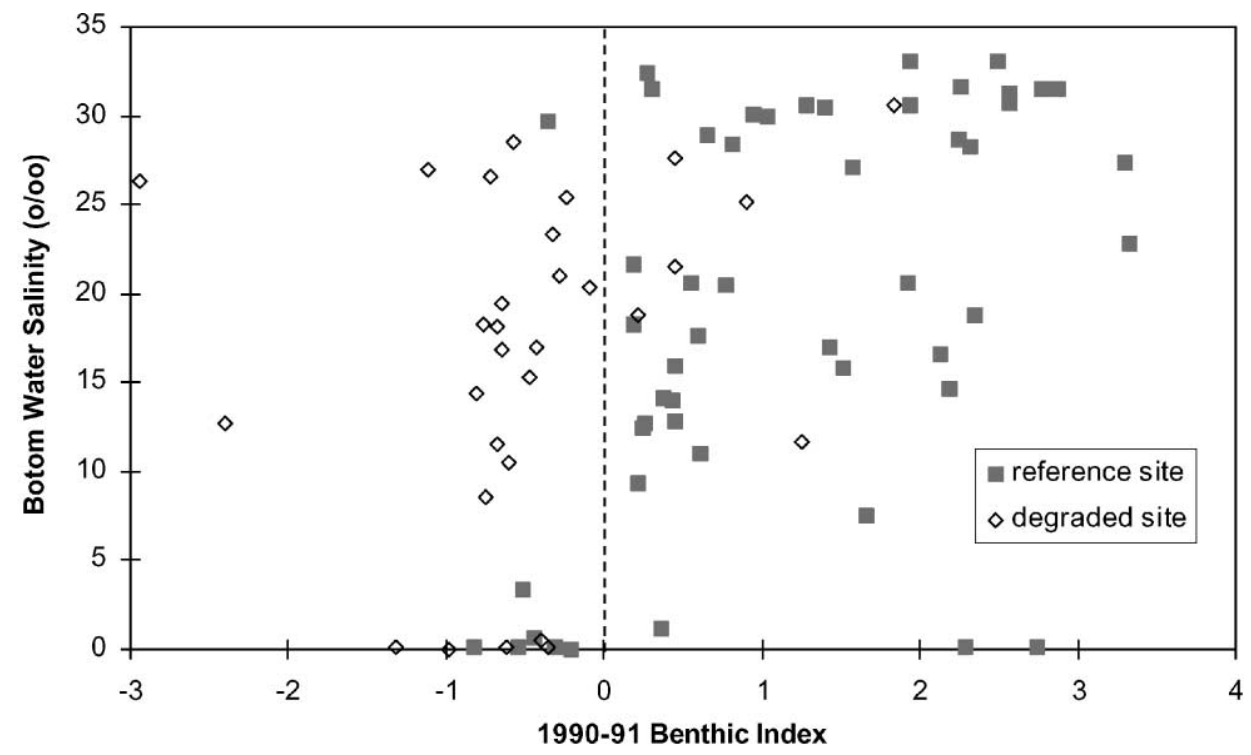

Fig. 2. The 1990-1991 benthic index vs. bottom water salinity for 1990-1991 calibration data (Schimmel et al., 1994). Negative benthic index values indicate degraded conditions. 
Additional grab samples of sediment for measuring chemical properties and toxicity were collected at each station. The top $2 \mathrm{~cm}$ of sediment was removed from multiple grabs and homogenized. Sediments were analyzed for 24 polycyclic aromatic hydrocarbons (PAHs), 18 congeners of polychlorinated biphenyls (PCBs), DDTs, 11 chlorinated pesticides, tributyl tins, and 15 metals. The acute toxicity of each composited sediment was tested on the tube-dwelling amphipod Ampelisca abdita by applying standard 10-day tests (U.S. EPA, 1995, taken from U.S. EPA, 1994). For more details on sampling and analysis, see Strobel et al. (1995). All data used in this study are available through EMAP's web site (www.gov.epa/emap).

\subsection{Identifying potential benthic metrics}

Data on benthic abundance, biomass, and species composition were used to define descriptors of the major ecological attributes of the benthic assemblages for each sampling site (Table 1). Additional metrics of benthic diversity, not considered for earlier indices, were evaluated, including Shannon's $H^{\prime}$ (or Shannon-Wiener index), Simpson's $D$, Gleason's $D$, and Pielou's evenness (Washington, 1984). Each was computed for the infauna, the epifauna, and the infauna plus epifauna. The additional metrics are defined, using notation in Washington (1984):

Shannon's $H^{\prime}: \quad H^{\prime}=-\sum_{u=1}^{S} \frac{n_{i}}{N} \log _{10} \frac{n_{i}}{N}$,

Simpson's $D: \quad D=\sum_{i=1}^{S} \frac{n_{i}\left(n_{i}-1\right)}{N(N-1)}$,

Gleason's $D: \quad D=\frac{S}{\ln N}$,

Pielou's evenness $E: \quad E=\frac{\text { Shannon's } H^{\prime}}{\log _{10} S}$,

where $n_{i}$ is the number of individuals for species $i$, $N$ the total number of individuals, and $S$ the number of species. Each potential metric was subjected to a $t$-test for equality of means at the reference and degraded sites. The direction of the $t$-test result (positive/negative) was compared with the sign of the candidate metric in potential indices.
The nature of estuaries, as interfaces between rivers and seas, creates large natural variations in certain of their physicochemical attributes (e.g. salinity, sediment grain size) known to control the abundance and diversity of resident biota. These attributes need to be identified and accounted for before the responses of potential benthic measures of environmental stress can be characterized accurately. Pearson correlation coefficients were calculated to determine the relationships between the individual metrics listed in Table 1 and physical characteristics of habitat such as the content of silt and clay in sediments, bottom water salinity, water depth, and latitude.

Each benthic metric in Table 1 whose correlation with a habitat variable accounted for $>25 \%$ of the variance (i.e. $r^{2} \geq 0.25$ ) was normalized using a polynomial regression for that habitat variable. For example, a regression against salinity was established by fitting the 90th percentile of a 3\%o (salinity) moving average of the individual benthic metric versus salinity. The specifics of this procedure are discussed in Weisberg et al. (1993).

\subsection{Developing the test data}

The 1990-1993 data included 539 sites with concurrent, quality-assured data for the benthic assemblage, bottom dissolved oxygen, bottom salinity, sediment toxicity, and sediment contaminants (Strobel and Valente, 1995). The benthic index was constructed from a subset of these sites. Point-in-time measurements obtained with the CTD were used for dissolved oxygen and salinity.

Sites classified as degraded had to meet at least one of these criteria:

1. Toxicity of sediments: survival $<80 \%$ of control and significantly different from controls.

2. Sediment contamination: at least one exceedence of Long et al.'s (1995) effects range-median (ER-M) values or $>10$ exceedences of effects range-low (ER-L) values.

3. Concentration of bottom dissolved oxygen $\leq 2$ $\mathrm{mg} / \mathrm{l}$.

Sites classified as reference had to meet all of these criteria: 
Table 1

Candidate benthic metrics used to formulate the benthic index ${ }^{\mathrm{a}}$

\begin{tabular}{|c|c|c|}
\hline Candidate benthic metrics & $\begin{array}{l}\text { Student's } t \text {-test } \\
(P \text {-value })\end{array}$ & $\begin{array}{l}\text { Direction }(+ \text { : greater mean } \\
\text { value at reference sites })\end{array}$ \\
\hline \multicolumn{3}{|l|}{ Measures of biodiversity } \\
\hline Shannon's $H^{\prime}$ based on total infauna & $<0.001$ & + \\
\hline Shannon's $H^{\prime}$ based on total epifauna & 0.01 & + \\
\hline Shannon's $H^{\prime}$ based on total infauna and epifauna & $<0.001$ & + \\
\hline Simpson's $D$ based on total infauna & 0.003 & - \\
\hline Simpson's $D$ based on total epifauna & 0.02 & - \\
\hline Simpson's $D$ based on total infauna and epifauna & 0.006 & - \\
\hline Gleason's $D$ based on total infauna & $<0.001$ & + \\
\hline Gleason's $D$ based on total epifauna & 0.007 & + \\
\hline Gleason's $D$ based on total infauna and epifauna & $<0.001$ & + \\
\hline Pielou's evenness based on total infauna & 0.004 & + \\
\hline Pielou's evenness based on total epifauna & 0.11 & + \\
\hline Pielou's evenness based on total infauna and epifauna & 0.007 & + \\
\hline Total number of infaunal species/site & $<0.001$ & + \\
\hline Total number of epifaunal species/site & 0.006 & + \\
\hline Mean number of infaunal species/grab & $<0.001$ & + \\
\hline Mean number of epifaunal species/grab & 0.007 & + \\
\hline \multicolumn{3}{|l|}{ Measures of community condition } \\
\hline Total benthic biomass per site & 0.76 & + \\
\hline Mean biomass per grab & 0.76 & + \\
\hline Mean infaunal abundance per grab & 0.11 & - \\
\hline Mean epifaunal abundance per grab & 0.07 & + \\
\hline \multicolumn{3}{|l|}{ Measures of individual health } \\
\hline Biomass/abundance ratio & 0.31 & + \\
\hline Mean weight of individual bivalves & 0.49 & - \\
\hline Mean weight of individual molluscs & 0.46 & - \\
\hline Mean weight of individual polychaetes & 0.39 & - \\
\hline Mean weight of all individual organism minus molluscs & 0.36 & + \\
\hline \multicolumn{3}{|l|}{ Measures of functional groups } \\
\hline Mean abundance of dominant species & 0.08 & - \\
\hline Mean abundance of opportunistic species & 0.03 & - \\
\hline Mean abundance of opportunistic species minus amphipods & 0.01 & - \\
\hline Mean abundance of equilibrium species & 0.1 & + \\
\hline Mean abundance of suspension feeding species & 0.48 & - \\
\hline Mean abundance of deposit feeding species & 0.04 & - \\
\hline Mean abundance of omnivore/carnivore species & 0.003 & + \\
\hline \multicolumn{3}{|l|}{ Measures of taxonomic composition } \\
\hline Mean abundance of amphipods & 0.05 & + \\
\hline Mean abundance of bivalves & 0.3 & - \\
\hline Mean abundance of gastropods & 0.03 & + \\
\hline Mean abundance of molluscs & 0.44 & - \\
\hline Mean abundance of polychaetes & 0.68 & + \\
\hline Mean abundance of capitellid polychaetes & 0.17 & + \\
\hline Mean abundance of spionid polychaetes & 0.14 & - \\
\hline Mean abundance of tubificid oligochaetes & 0.06 & - \\
\hline $\begin{array}{l}\text { Abundance ratio of Limnodrius hoffmeisteri and Streblospio } \\
\text { benedicti to all infauna }\end{array}$ & 0.58 & - \\
\hline
\end{tabular}

${ }^{a}$ Total refers to number for three grab samples. Mean refers to mean for three grab samples. The $t$-tests were used to test equality of the means for each metric for reference and degraded sites in the calibration data. 
1. No contaminant in sediment exceeded an ER-M value, and no more than three contaminants exceeded ER-L values.

2. Sediment was not toxic (i.e. survival rates exceeded $80 \%$ of controls and did not differ significantly from them).

3. Bottom dissolved oxygen $\geq 7 \mathrm{mg} / \mathrm{l}$.

These criteria were more restrictive than those used in the earlier versions of the benthic index. The sites that met these criteria were subdivided into sets for calibrating and validating the index.

\subsection{Identifying and validating combinations of benthic metrics}

The benthic measures that best discriminated between the reference and degraded sites were identified by successive linear discriminant analyses (LDAs) of the calibration data and were checked with the validation data. The LDA was initially conducted using all of the metrics. Subsequent LDAs were conducted using additional metrics, eliminating selected metrics, and/or limiting the number of variables in the discriminant function. The SAS procedure for stepwise discriminant analysis, STEPDISC (SAS, 1990), was used to select a subset of the metrics that best revealed differences between the reference and degraded sites. The discriminant function was then derived from that subset of metrics with the SAS procedure DISCRIM (SAS, 1990). The targets for correct classification during calibration and validation were set at 90 and $80 \%$, respectively. During calibration, the sensitivity of the index to individual sites was determined from the cross-validation classification feature of DISCRIM. Cross-validation is a technique to assess the reliability in reproducing site classification in which each site is removed, and the discriminant function based on the remaining sites is then used to classify the site that was removed.

\section{Results}

\subsection{Potential benthic metrics}

Although many potential benthic metrics correlated significantly $(P<0.05)$ with one or more of the habitat variables (Table 2), only seven of the correlations explained $>25 \%$ of the variance $\left(r^{2} \geq 0.25\right)$, and they all involved positive correlations with bottom salinity. The seven metrics expressed species richness (total number of infaunal/epifaunal species and mean number of infaunal/epifaunal species) and diversity (Shannon's $H^{\prime}$ based upon epifauna and Gleason's $D$ based upon infauna and epifauna plus infauna). The correlations of the potential metrics with the other habitat variables (latitude, silt-clay content of sediments, bottom-water temperature, and water depth) were smaller, and accounted for less of the total variation than the relationships with salinity (Table 2). Refer to Paul et al. (1999) for details of salinity normalization.

The seven metrics normalized to salinity were added to the list of potential measures and were checked for possible correlations with the habitat variables. No significant correlations $\left(r^{2} \geq 0.25\right)$ were found. The complete list of metrics (48 total) comprised those identified in Table 1 plus the seven normalized for salinity.

\subsection{Calibration data}

The calibration data selected from the 1990 to 1993 data contained 60 sites, 30 reference and 30 degraded

Table 2

Summary of correlations between habitat variables and the candidate benthic metrics for the entire 1990-1993 data set, using Pearson correlation coefficients (significance at $P<0.05$ ).

\begin{tabular}{llll}
\hline Habitat variables & $\begin{array}{l}\text { Number of significant } \\
\text { correlations }\end{array}$ & $\begin{array}{l}\text { Number of correlations } \\
\text { with } r^{2} \geq 0.10\end{array}$ & $\begin{array}{l}\text { Number of correlations } \\
\text { with } r^{2} \geq 0.25\end{array}$ \\
\hline Bottom water salinity & 37 & 11 & 7 \\
Latitude & 30 & 0 & 0 \\
Bottom water temperature & 32 & 8 & 0 \\
Silt-clay content of sediments & 27 & 9 & 0 \\
Water depth & 24 & 1 & 0 \\
\hline
\end{tabular}


(see Paul et al., 1999, for the actual sites). Each group contained 10 sites per salinity zone $(<5,5-18$, and $>18 \%$ ). These zones are the same as those used by Weisberg et al. (1993) and Schimmel et al. (1994), and represent freshwater/oligohaline, mesohaline, and polyhaline waters. Each category was trimmed to 10 sites so as to give the desired equal numbers of sites in each of the six categories. For categories with $>10$ satisfactory sites, the final sites were selected to represent the best of reference or the worst of degraded sites and maintain a balance across sediment grain sizes. The 52 sites that were not used for calibrating were reserved for validation. The geographic distribution of the calibration and validation sites is shown in Fig. 3.

\subsection{Identifying and validating combinations of benthic metrics}

The results of the linear discriminant analyses are summarized in Table 3. The first stepwise discriminant analysis yielded six variables that were combined into Index 1. This index missed the target for correctly classifying the reference sites for calibration and cross-validation, but met the target for validation. Index 1 appeared to have two potential concerns: (1) Pielou's evenness based upon infauna and polychaete abundance entered the discriminant function with negative coefficients, in contrast to how these metrics were expected to respond and inconsistent with

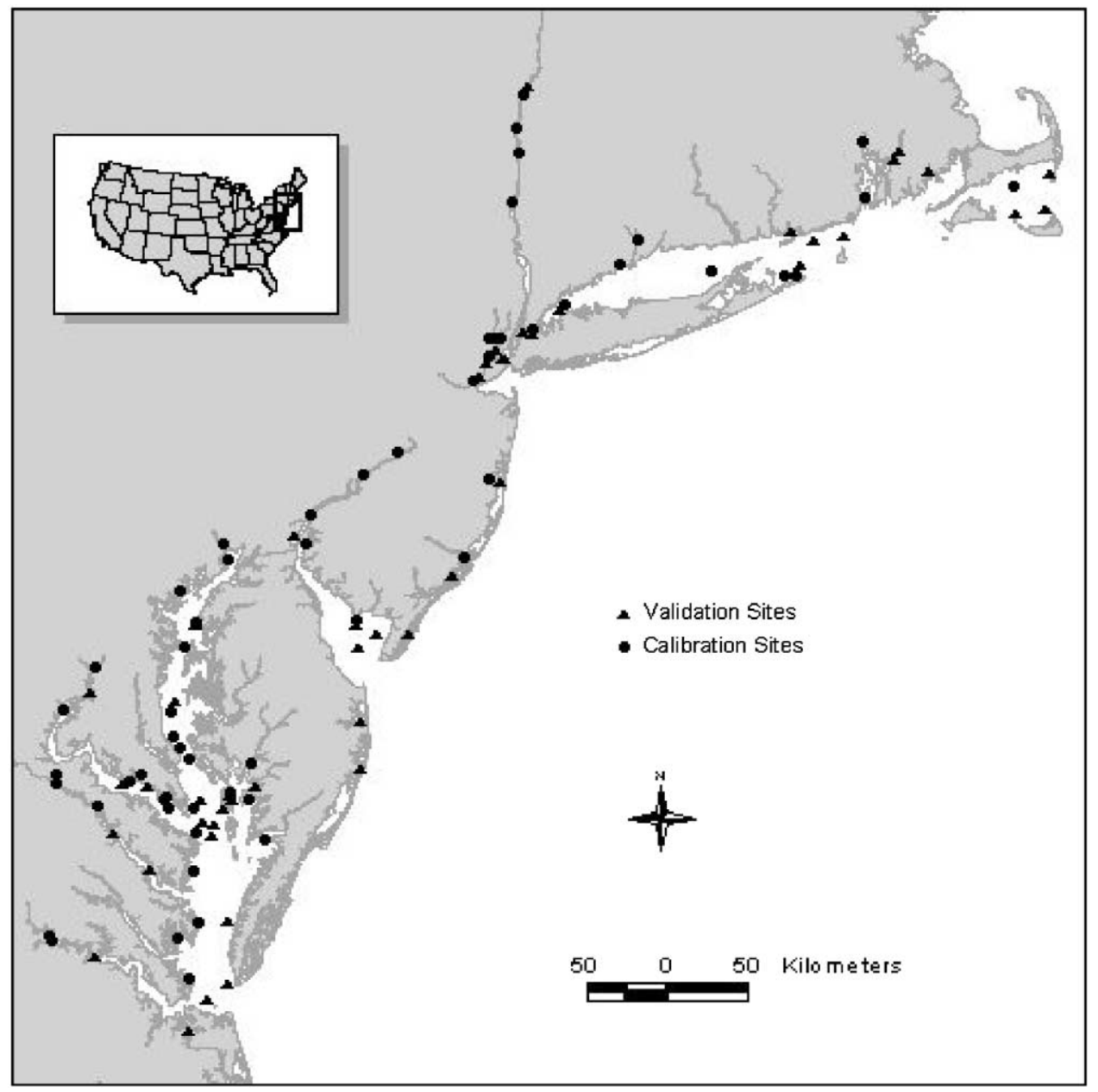

Fig. 3. Geographic distribution of sites used for calibration and validation of 1990-1993 EMAP Virginian Province benthic index. 
Table 3

Results of linear discriminant analyses conducted to combine candidate benthic metrics into an index of benthic condition for the 1990-1993 EMAP Virginian Province data

\begin{tabular}{|c|c|c|c|c|c|c|c|c|}
\hline \multirow[t]{2}{*}{ Analysis } & \multirow[t]{2}{*}{ Selected measures } & \multirow[t]{2}{*}{ Coefficients } & \multicolumn{2}{|c|}{ Calibration } & \multicolumn{2}{|c|}{ Cross-validation } & \multicolumn{2}{|l|}{ Validation } \\
\hline & & & $\begin{array}{l}\text { Classify } \\
\text { reference } \\
\text { sites }(\%)\end{array}$ & $\begin{array}{l}\text { Classify } \\
\text { degraded } \\
\text { sites }(\%)\end{array}$ & $\begin{array}{l}\text { Classify } \\
\text { reference } \\
\text { sites }(\%)\end{array}$ & $\begin{array}{l}\text { Classify } \\
\text { degraded } \\
\text { sites }(\%)\end{array}$ & $\begin{array}{l}\text { Classify } \\
\text { reference } \\
\text { sites }(\%)\end{array}$ & $\begin{array}{l}\text { Classify } \\
\text { degraded } \\
\text { sites }(\%)\end{array}$ \\
\hline Index 1 & $\begin{array}{l}\text { Salinity normalized Gleason's } D \text { based upon infauna } \\
\text { Tubificid abundance } \\
\text { Epifauna abundance } \\
\text { Polychaete abundance } \\
\text { Pielou's evenness based upon Infauna } \\
\text { Shannon's } H^{\prime} \text { based upon infauna }\end{array}$ & $\begin{array}{r}1.214 \\
-0.698 \\
0.313 \\
-0.487 \\
-0.759 \\
0.902\end{array}$ & 83 & 93 & 77 & 90 & 85 & 81 \\
\hline Index 2 & $\begin{array}{l}\text { Salinity normalized Gleason's } D \text { based upon infauna } \\
\text { Salinity normalized tubificid abundance } \\
\text { Epifauna abundance } \\
\text { Pielou's evenness based upon Infauna } \\
\text { Polychaete abundance } \\
\text { Shannon's } H^{\prime} \text { based upon infauna and epifauna }\end{array}$ & $\begin{array}{r}1.267 \\
-0.775 \\
0.446 \\
-0.762 \\
-0.483 \\
0.823\end{array}$ & 90 & 97 & 87 & 93 & 81 & 81 \\
\hline Index 3 & $\begin{array}{l}\text { Salinity normalized Gleason's } D \text { based upon infauna } \\
\text { Salinity normalized tubificid abundance } \\
\text { Epifauna abundance }\end{array}$ & $\begin{array}{r}1.404 \\
-0.641 \\
0.354\end{array}$ & 90 & 93 & 90 & 93 & 81 & 65 \\
\hline Index 4 & $\begin{array}{l}\text { Salinity normalized Gleason's } D \text { based upon infauna and epifauna } \\
\text { Salinity normalized tubificid abundance } \\
\text { Spionid polychaete abundance }\end{array}$ & $\begin{array}{r}1.389 \\
-0.651 \\
-0.375\end{array}$ & 87 & 90 & 87 & 87 & 88 & 81 \\
\hline Index 5 & $\begin{array}{l}\text { Salinity normalized Gleason's } D \text { based upon infauna and epifauna } \\
\text { Salinity normalized tubificid abundance } \\
\text { Spionid polychaete abundance } \\
\text { Shannon's } H^{\prime} \text { based upon infauna }\end{array}$ & $\begin{array}{r}1.292 \\
-0.645 \\
-0.367 \\
0.114\end{array}$ & 90 & 90 & 87 & 87 & 88 & 81 \\
\hline Index 6 & $\begin{array}{l}\text { Salinity normalized total number of infaunal species } \\
\text { Salinity normalized tubificid abundance } \\
\text { Gleason's } D \text { based upon infauna } \\
\text { Polychaete abundance } \\
\text { Epifauna abundance }\end{array}$ & $\begin{array}{r}1.068 \\
-0.835 \\
0.623 \\
-0.576 \\
0.345\end{array}$ & 90 & 97 & 83 & 93 & 81 & 81 \\
\hline
\end{tabular}


the $t$-test directions in Table 1; and (2) exploratory analysis indicated that tubificid abundance might have to be normalized to salinity in order to correct for the misclassification of low salinity reference sites. Salinity-normalized abundance of tubificids was added to the list of metrics for the LDA. This normalization required a different procedure than used with the other benthic metrics because tubificids, in the taxonomic enumeration, only were identified separately for low salinity $(<5 \%$ ) waters, and occurred in greater abundances at degraded sites than at reference sites. The normalization procedure was

salinty-normalized tubificid abundance

$$
=\text { tubificid abundance }
$$

$$
-500 \times \exp (-15 \times \text { bottom salinity }),
$$

where $\exp (\ldots)$ denotes the exponential function. Note that the normalized abundance is positive for degraded sites and negative for reference sites.

Index 2 included six variables, one of which was salinity-normalized abundance of tubificids. This index met the targets for calibration, cross-validation, and validation. However, both Pielou's evenness (based upon infauna) and polychaete abundance entered the discriminant function with negative coefficients, in contrast to how macrobenthic communities at reference and degraded sites were expected to respond, and inconsistent with the $t$-test directions in Table 1.

Index 3 was developed similarly to Index 2, but selecting only the first three metrics identified by the stepwise discriminant analysis. This eliminated the variables that contributed to the discriminant function in an unexpected direction. Index 3 met the target for calibration and cross-validation, but missed the target for validation at degraded sites.

Index 4 was developed by removing salinity-normalized Gleason's $D$ based upon infauna (the first metric to enter for Index 1, 2, and 3) from the list of metrics and keeping the first three metrics identified. It missed the goal for calibration by one site, but met the targets for cross-validation and validation.

Index 5 resembled Index 4, but retained all four metrics identified by the stepwise discriminant analysis. It met the targets for calibration, cross-validation, and validation. It offered minimal improvement over Index 4 by including a metric with a small coefficient in the discriminant function (Shannon's $H^{\prime}$ based on infauna).

Index 6 was developed similarly to Index 4, but after removing the salinity-normalized Gleason's $D$ based upon infauna and epifauna (the first metric to enter for Index 4) from the list of metrics. It included five variables. Index 6 met the targets for classification, cross-validation, and validation. Polychaete abundance entered the discriminant function with a negative coefficient, in contrast to the $t$-test direction in Table 1 and to how benthic communities were expected to respond.

\subsection{Selecting an index}

Benthic Index 4 was selected for the 4-year assessments in the Virginian Province (Strobel et al., 1995; Paul et al., 1999). Although it did not meet the target for calibration with reference sites, it missed by only one site. Benthic Index 5 classified the calibration samples marginally better, but the small improvement did not seem to justify including a metric with a small coefficient in the discriminant function. To check whether Index 5 could identify degraded areas better, the spatial patterns for the complete 1990-1993 data were determined with both indices and were indistinguishable. The two indices classified only 7 of the 630 sites differently.

Because the calibration data contained the same number of reference and degraded sites, the demarcation in the discriminant function score between reference and degraded sites was zero. The benthic index did not have to be scaled (linearly transformed) to set the demarcation at zero, as had been necessary with earlier versions of the benthic index (Weisberg et al., 1993; Schimmel et al., 1994).

To check whether the 1990-1993 benthic index worked better than the 1990-1991 index, the earlier index was applied to the 4-year calibration and validation data. It correctly classified 77 and $90 \%$ of the reference and degraded sites, respectively, with the calibration data and 92 and $65 \%$ of the sites with the validation data. Thus, it scored $85 \%$ for reference sites and $78 \%$ for degraded sites in the combined data. A salinity bias was found for the reference sites (Fig. 4). The 1990-1993 index proved superior: it scored $86 \%$ for both the reference and degraded sites in the combined data. 


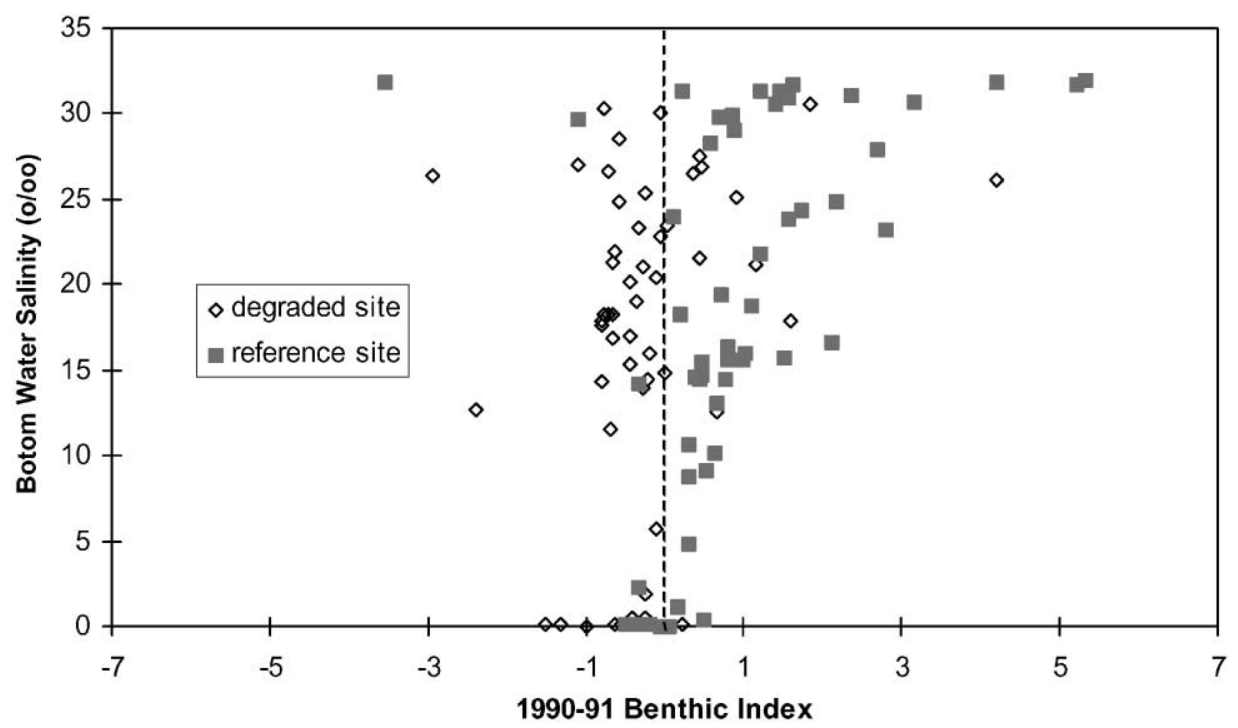

Fig. 4. The 1990-1991 benthic index vs. bottom salinity for combined 4-year calibration and validation data. Negative benthic index values indicate degraded conditions.

\subsection{Formula for the 1990-1993 benthic index}

The three benthic metrics in the final 1990-1993 benthic index (Index 4) are: salinity-normalized Gleason's $D$ based upon infauna and epifauna, salinity-normalized tubificid abundance, and abundance of spionids. The linear discriminant function normalizes the individual metrics using their means and standard deviations in the calibration data. Letting SNGD: salinity-normalized Gleason's $D$ based on infauna and epifauna, GD: Gleason's $D$ based on infauna and epifauna, SNTA: salinity-normalized tubificid abundance, TA: tubificid abundance, SA: spionid abundance, and SB: bottom salinity, the formula for the 1990-1993 benthic index for EMAP's Virginian Province is

$$
\begin{aligned}
\text { benthic index }= & \frac{1.389 \times(\mathrm{SNGD}-51.5)}{28.4} \\
& -\frac{0.651 \times(\mathrm{SNTA}-28.2)}{119} \\
& -\frac{0.375 \times(\mathrm{SA}-20.0)}{45.4} \\
= & 0.0489 \times \mathrm{SNGD}-0.00545 \times \mathrm{SNTA} \\
& -0.00826 \times \mathrm{SA}-2.20
\end{aligned}
$$

where

$$
\mathrm{SNGD}=\frac{100 \times \mathrm{GD}}{\begin{array}{c}
4.283-0.498 \times \mathrm{SB}+0.0542 \\
\times \mathrm{SB}^{2}-0.00103 \times \mathrm{SB}^{3}
\end{array}}
$$

and

$\mathrm{SNTA}=\mathrm{TA}-500 \times \exp (-15 \times \mathrm{SB})$,

and $\exp (\ldots)$ denotes the exponential function. Reference conditions are for benthic index $>0$, and degraded conditions are for benthic index $\leq 0$.

\subsection{Applying the benthic index}

The benthic index from the 1990 to 1993 data indicated that benthic communities were degraded in $25 \pm 3 \%$ (mean $\pm 95 \%$ confidence interval) of the Virginian Province's estuarine waters, $19 \pm 4 \%$ of the Province's large open water areas, $37 \pm 6 \%$ of the small estuarine systems, and $38 \pm 14 \%$ of the large tidal rivers. Degraded benthic communities were found in $23 \pm 5 \%$ of the area of Chesapeake Bay, $24 \pm 12 \%$ of Delaware Bay, $72 \pm 8 \%$ of the Hudson-Raritan system, and $28 \pm 11 \%$ of Long Island Sound. More-detailed applications of the benthic index 
and discussions of the results appear in Paul et al. (1999) and Strobel et al. (1995, 1999).

\section{Discussion}

Of the three metrics in the benthic index for the Virginian Province, salinity-normalized Gleason's $D$ for infauna and epifauna contributes positively, spionid abundance and salinity-normalized tubificid abundance negatively. Gleason's $D$, one of the earlier diversity indices, normalizes total number of species by the logarithm of the total number of individuals (Gleason, 1922). It assumes that the number of individuals is proportional to the area. Gleason's $D$ can be viewed as an approximation to (and more readily computable than) Shannon's $H^{\prime}$. According to Washington (1984), this index has not been used extensively in recent literature. Spionids (sometimes referred to as mudworms, e.g. O'Connor et al., 1999) are considered to be stress-tolerant taxa (Jewett et al., 1999). Tubificids (sometimes referred to as sludgeworms, e.g. Egeler et al., 1997) are indicators of organic pollution (Brinkhurst and Kennedy, 1965;
Cook and Brinkhurst, 1973; Chapman and Brinkhurst, 1993) and of toxic pollutants (Reible et al., 1996; Leynen et al., 1999).

The benthic index is positive for reference sites and negative for degraded sites. The two negatively contributing metrics work complementarily: spionid abundance discriminates degraded sites for saline waters, tubificid abundance for tidal fresh/oligohaline waters. This combination, along with the salinity normalization for the diversity metric, allows the index to work effectively over the full range of salinities in Virginian Province estuaries. Fig. 5 shows the index applied to the entire Virginian Province data. It is free of the salinity bias that was apparent in the 1990-1991 index (Fig. 1). The correlation of benthic index with salinity is not significant $(P=0.21)$.

Gallagher and Keay (1998) reported that spionids are abundant in areas such as Massachusetts and Cape Cod Bays. They noted that pollutant-tolerant opportunistic spionid taxa such as Polydora cornuta and Streblospio benedicti were very abundant in organically enriched Boston Harbor, but were rare or absent in sediments of outer Massachusetts Bay and Cape Cod Bay. In contrast, spionid species abundant in outer

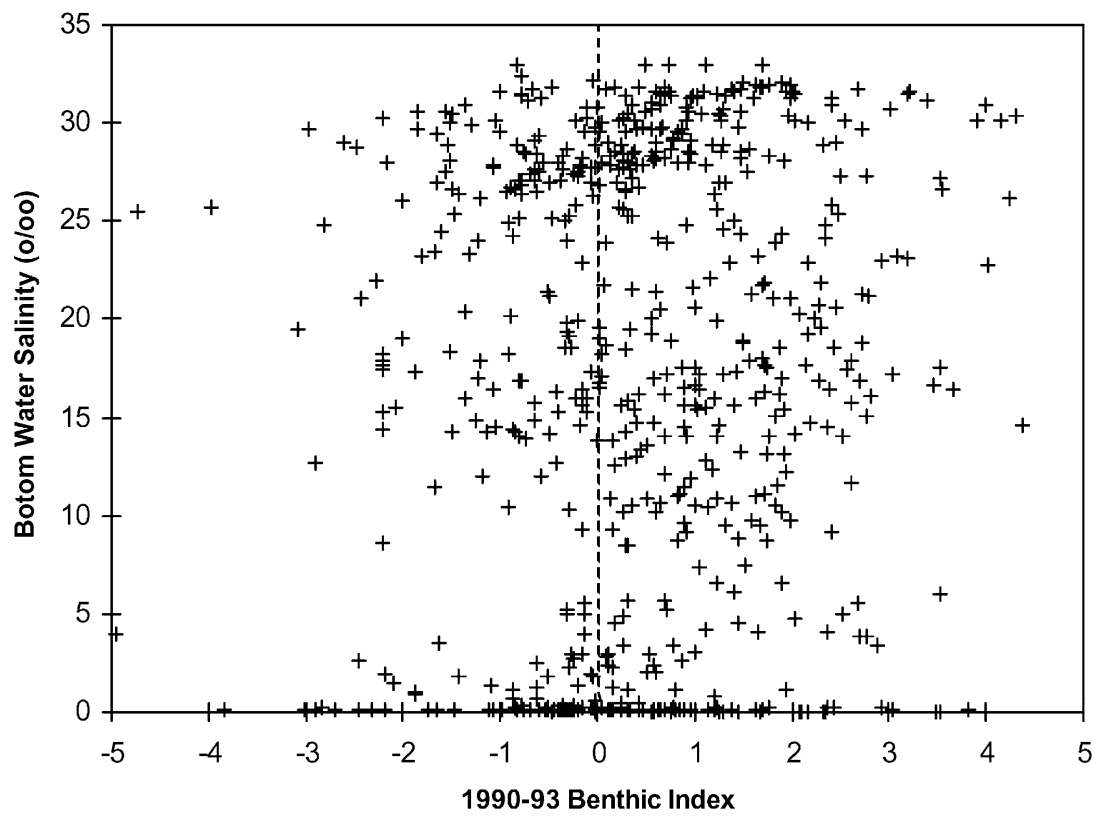

Fig. 5. The 1990-1993 benthic index vs. bottom water salinity for 1990-1993 EMAP Virginian Province data. Negative benthic index values indicate degraded conditions. 
Massachusetts Bay and Cape Cod Bay were pollutant intolerant. To explore this issue, abundances of $P$. cornuta and $S$. benedicti were substituted for the spionid abundance in the linear discriminant analysis, and almost identical classification percentages were obtained with Index 4 for the calibration data $(87 \%$ for reference sites and $90 \%$ for degraded sites) and cross-validation data $(87 \%$ for reference sites and $90 \%$ for degraded sites). The results with the validation data ( $89 \%$ for reference sites and $73 \%$ for degraded sites) fell short of the target, however. These results did not justify changing the benthic index (Eq. (3)).

Our approach for developing a benthic index for the Virginian Province resembles that used by Engle et al. (1994) and Engle and Summers (1999) for estuaries in the Gulf of Mexico (Louisianian Province). In fact, Engle et al. (1994) based their work on the original Virginian Province approach reported by Weisberg et al. (1993). The components of the Louisianian Province's index are similar to those in the index presented here-a positive diversity component (Shannon-Wiener diversity index (Shannon's $H^{\prime}$ ) adjusted for salinity), negative components for abundance of tubificids and relative abundances of capitellids and bivalves, and a positive component for relative abundance of amphipods. These authors clearly state that the benthic index developed for the Louisianian Province should not be applied to other Biogeographic Provinces because of inherent differences in macrobenthic communities. The index presented here is appropriate for application in the Virginian Province.

Another approach to developing a benthic index was used by Weisberg et al. (1997) for their Chesapeake Bay estuarine benthic index of biotic integrity (B-IBI), which in turn followed the approach developed by Karr for the index of biotic integrity (IBI) (Karr, 1981; Kerans and Karr, 1994; DeShon, 1995; Karr and Chu, 1999). It is a habitat-based multimetric index that estimates the degree to which a site meets the targets of restoring the Chesapeake Bay's benthic community. Engle and Summers (1999) discuss potential shortcomings of the IBI approach applied to estuarine macrobenthic communities.

The B-IBI was developed for three low-salinity habitats $(<0.5,0.5-5,5-12 \%)$, and four high salinity habitats (12-18 and $>18 \%$ for two ranges of grain size (silt-clay content of $<40$ and $>40 \%$ )). Correct site classification using the validation data was within the range $50-100 \%$ for the different habitats. Each habitatspecific B-IBI contains 4-7 metrics, with ShannonWiener index, abundance, biomass, and abundance of pollutant-intolerant taxa being common to all.

This paper's index is different from the B-IBI in several ways:

1. We developed a single index for each site by using metrics normalized to salinity, whereas a separate B-IBI was developed for each stratum of habitat (combination of salinity and sediment grain size).

2. We developed our index with reference and degraded sites. In contrast, thresholds were developed for each of the B-IBI's metrics by using only conditions at reference sites. The B-IBI was validated with degraded sites and a separate set of reference sites.

3. The Virginian Province benthic index used a linear discriminant function for differentiating conditions at reference and degraded sites. The B-IBI scores were assigned to sites by using specified percentiles from cumulative distributions of individual metrics. For example, a metric was scored as 5, 3, or 1 depending on whether its value at a site approximates, deviates slightly from, or deviates greatly from the median value for the reference sites.

When the Chesapeake Bay B-IBI was compared with the Virginian Province benthic index, both classified $85 \%$ of 239 Chesapeake Bay sites the same way (Ranasinghe et al., 1998b). Benthic experts at a workshop convened to review these benthic indices agreed that the 35 sites classified differently contained marginal benthic communities whose characteristics did not allow them to be classified clearly. Those sites were in transitional areas between reference and degraded areas. Values of both indices for the conflicting sites were also between those for reference and degraded sites. Because confidence intervals were not calculated for the indices and sensitivity analyses were not run, Ranasinghe et al. (1998b) concluded that the conflicting classifications did not represent any weakness in the indices.

The Virginian Province benthic index represented in Eq. (3) is based on data from three replicate grab samples per site. In practice, three replicate grabs are not always taken or available: samples can be lost or compromised, and some monitoring programs collect a single grab per site (e.g., Ranasinghe et al., 1998a). 
The coefficients for the metrics in Eq. (3) were adjusted for cases where fewer than three replicate grabs are available (see Appendix A). The formula for the index derived from a single grab at a site is

$$
\begin{gathered}
0.0492 \times \text { SNGD }-0.00445 \times \text { SNTA } \\
-0.00662 \times \text { SA }-1.73
\end{gathered}
$$

The Virginian Province's benthic index correctly classified $88 \%$ of reference sites and $81 \%$ of degraded sites with independent data (Table 3). To increase the credibility of this index, future work will validate it with other independent data from the Virginian Province. Possible sets include the New Bedford Harbor Project (Nelson et al., 1996) and the New York/New Jersey Harbor Sediment Quality Project (Adams et al., 1998).

\section{Conclusion}

A benthic index of estuarine condition was successfully constructed for the Virginian Province using EMAP data from 1990 to 1993 . The selection of the index was based on the ecological interpretation and relevance of the individual metrics and the ability to meet the calibration and validation targets. The index can be used as an ecological indicator of benthic community condition across the full range of salinity habitats (tidal freshwater to full-strength seawater) and grain-size habitats (silt-clay to sand) found in the estuarine waters of the Virginian Province.

\section{Acknowledgements}

The authors wish to thank Wayne Davis, Lesa Meng, Peg Pelletier, Rick Kutz, Dave Russell, Ken Rahn, and two anonymous reviewers for the critical and constructive reviews that they provided, and Jim Heltshe for discussions on statistical issues. Steve Weisberg, Fred Holland, and Ananda Ranasinghe contributed to the 1990 benthic index development; Charlie Strobel and Ray Valente to the 1990-1991 index; and John Paul, John Scott, Dan Campbell, and Jack Gentile to the 1990-1993 index. The research described in this paper has been funded in part by the United States Environmental Protection Agency
(Environmental Monitoring and Assessment Program, Office of Research and Development) through the Atlantic Ecology Division. Support for SAIC was provided by EPA Contract \#68-01-0005, M.P. Gant, Project Officer. This paper has not been subjected to Agency review. Therefore, it does not necessarily reflect the views of the Agency. Mention of trade names or commercial products does not constitute endorsement or recommendation for use. This is contribution number NHEERL-NAR-2188 of the Atlantic Ecology Division, National Health and Ecological Effect Research Laboratory.

\section{Appendix A}

The benthic index in Eq. (3) was developed with data from sampling sites that had three replicate grab samples of benthos. The major assumption in adjusting to data from a single grab sample is that the same metrics will be used. Three procedures were evaluated to modify Eq. (3) for a single grab sample:

1. independent linear regressions on each individual metric in Eq. (3);

2. linear regression on all three metrics in Eq. (3);

3. linear discriminant analyses using the metrics in Eq. (3).

These procedures were explored with the calibration and validation data. Randomization techniques (Manly, 1997) were used to select one of the three grab samples for each site, treating each selection independently from the other sites. Using the calibration data, 1000 simulations with randomly selected single-grab data were run for each procedure to determine the modified coefficients. The results were then evaluated by applying the modified coefficients to the calibration and validation sets and comparing the classifications of reference and degraded sites. This procedure used 1000 simulations with the modified Eq. (3) using randomized selection of a single grab for each of the 60 calibration sites and each of the 52 validation sites. Randomizations were done because of the large number of possible combinations: $3^{60}$ for calibration sites and $3^{52}$ for validation sites.

Salinity-normalized Gleason's $D$ is the only metric in Eq. (3) that is directly affected by the number of grabs, since it is based on the total number of species 
and total abundance for three grabs. The other two metrics are based on means per grab. Using the calibration data, 1000 simulations were conducted on linear regressions with zero intercepts for

$\mathrm{SNGD}_{3}=\alpha \times \mathrm{SNGD}_{1}$,

where $\mathrm{SNGD}_{3}$ is salinity-normalized Gleason's $D$ based on three grabs (term used in Eq. (3)) and $\mathrm{SNGD}_{1}$ is salinity-normalized Gleason's $D$ based on a single grab. The simulated median value for a was 1.247.

For evaluating the effectiveness of this procedure, the results for correct classification with the 1000 simulations are presented below:

\begin{tabular}{lll}
\hline & $\begin{array}{l}\text { Reference } \\
\text { sites }\end{array}$ & $\begin{array}{l}\text { Degraded } \\
\text { sites }\end{array}$ \\
\hline Calibration data $(\%)$ & 83 & 87 \\
Validation data $(\%)$ & 73 & 81 \\
\hline
\end{tabular}

For the second procedure, 1000 simulations were conducted on linear regressions with the value of the benthic index based on three grabs against the metrics evaluated for a single grab or

$$
\begin{aligned}
\mathrm{BI}_{3}= & \alpha_{1}+\alpha_{2} \times \mathrm{SNGD}_{1}+\alpha_{3} \\
& \times \mathrm{SNTA}_{1}+\alpha_{4} \times \mathrm{SA}_{1} .
\end{aligned}
$$

where $\mathrm{BI}_{3}$ is the benthic index based on three grabs, $\mathrm{SNTA}_{1}$ is salinity-normalized tubificid abundance based on a single grab, and $\mathrm{SA}_{1}$ is spionid abundance based on a single grab. For the 1000 simulations, the median regression coefficients were $\alpha_{1}=-1.769$, $\alpha_{2}=0.0506, \alpha_{3}=-0.00468$, and $\alpha_{4}=-0.00662$.

To evaluate the effectiveness of the second procedure, the median results for correct classification from the 1000 simulations are presented below:

\begin{tabular}{lll}
\hline & $\begin{array}{l}\text { Reference } \\
\text { sites }\end{array}$ & $\begin{array}{l}\text { Degraded } \\
\text { sites }\end{array}$ \\
\hline Calibration data (\%) & 87 & 83 \\
Validation data (\%) & 81 & 77 \\
\hline
\end{tabular}

For the third procedure, 1000 simulations were conducted with linear discriminant analyses with the metrics evaluated for single grabs. Based on the simu- lations, the discriminant function with the median coefficient values was

$$
\begin{aligned}
& \frac{1.246 \times(\mathrm{SNGD}-40.5)}{25.3} \\
& -\frac{0.555 \times(\mathrm{SNTA}-29.1)}{124.7} \\
& -\frac{0.344 \times(\mathrm{SA}-20.0)}{52.0},
\end{aligned}
$$

where the metrics are normalized by the mean and standard deviations of the metrics for single grabs over the entire calibration data set. An equivalent form of this discriminant function is

$$
\begin{gathered}
0.0492 \times \text { SNGD }-0.00445 \times \text { SNTA } \\
-0.00662 \times \mathrm{SA}-17.3
\end{gathered}
$$

To evaluate the effectiveness of this procedure, the median results from the 1000 simulations are presented below:

\begin{tabular}{lll}
\hline & $\begin{array}{l}\text { Reference } \\
\text { sites }\end{array}$ & $\begin{array}{l}\text { Degraded } \\
\text { sites }\end{array}$ \\
\hline Calibration data (\%) & 87 & 83 \\
Validation data (\%) & 81 & 77 \\
\hline
\end{tabular}

The coefficients determined by the second and third procedures are essentially the same. In fact, Dillon and Goldstein (1984) state that the two-group discriminant analysis is computationally indistinguishable from linear models in regression analysis. Therefore, based upon the results for correct classification, the coefficients determined by the linear discriminant analysis (third procedure) are used to calculate the benthic index for single-grab data.

\section{References}

Adams, D.A., O'Connor, J.S., Weisberg, S.B., 1998. Sediment Quality of the New York/New Jersey Harbor System. EPA/902R-98-001, US Environmental Protection Agency, Region 2, Edison, New Jersey.

Angradi, T.R., Hagan, S.M., Able, K.W., 2001. Vegetation type and the intertidal macroinvertebrate fauna of a brackish marsh: Phragmites versus Spartina. Wetlands 21 (1), 75-92.

Boesch, D.F., 1973. Classification and community structure of macrobenthos in the Hampton Roads area, Virginia. Marine Biol. 21, 226-244. 
Boesch, D.F., Rosenberg, R., 1981. Response to stress in marine benthic communities. In: Barret, G.W., Rosenberg, R. (Eds.), Stress Effects on Natural Ecosystems. Wiley, New York, pp. 179-200.

Brinkhurst, R.G., Kennedy, C.R., 1965. Studies on the biology of the Tubificidae (Annelids: Oligochaeta) in a polluted stream. J. Anim. Ecol. 34, 429-443.

Chapman, P.M., Brinkhurst, R.O., 1993. Lethal and sublethal tolerances of aquatic Oligochaetes with reference to their use as a biotic index of pollution. Hydrologica 115, 139-144.

Committee on Environment and Natural Resources CENR, 1997. Integrating the Nation's Environmental Monitoring and Research Networks and Programs. Committee on Environment and Natural Resources, National Science and Technology Council, Washington, DC.

Cook, D.G., Brinkhurst, R.O., 1973. Marine flora and fauna of the Northeastern United States, Annelid: Oligochaeta. Technical Report NMFS CIRC-374. National Oceanic and Atmospheric Administration, Washington, DC.

Cooley, W.W., Lohnes, P.R., 1971. Multivariate Data Analysis. Wiley, New York.

DeShon, J.E., 1995. Development and application of the invertebrate community index. In: Davis, W.P., Simon, T.P. (Eds.), Biological Assessment and Criteria. Lewis Publishers, Boca Raton, FL, pp. 217-243.

Dillon, W.R., Goldstein, M., 1984. Multivariate Analysis, Methods and Applications. Wiley, New York.

Egeler, P., Rombke, J., Meller, M., Knacker, T., Franke, C., Studinger, G., Nagel, R., 1997. Bioaccumulation of Lindane and hexachlorobenzene by tubificid sludgeworms (Oligochaeta) under standardized laboratory conditions. Chemosphere 35 (4), 835-852.

Engle, V.D., Summers, J.K., 1999. Refinement, validation, and application of a benthic condition index for northern Gulf of Mexico estuaries. Estuaries 22 (3A), 624-635.

Engle, V.D., Summers, J.K., Gaston, G.R., 1994. A benthic index of environmental condition of Gulf of Mexico estuaries. Estuaries 17 (2), 372-384.

Gallagher, E.D., Keay, K.K., 1998. Organism-sediment-contaminant interactions in Boston Harbor. In: Stolzenbach, K.D., Adams, E.E. (Eds.), Contaminated Sediment in Boston Harbor. MIT Sea Grant Press, Boston, Massachusetts, pp. 89-132.

Gesteira, J.L.G., Dauvin, J.C., 2000. Amphipods are Good Bioindicators of the Impact of Oil Spills on Soft-Bottom Macrobenthic Communities. Marine Poll. Bull. 40 (11), 1017-1027.

Gleason, H.A., 1922. On the relation between species and area. Ecology 3 (2), 158-162.

Gonzalez-Oreja, J.A., Saiz-Salinas, J.I., 1998. Exploring the relationships between abiotic variables and benthic community structure in a polluted estuarine system. Water Res. 32 (12), 3799-3807.

Graca, M.A.S., Coimbro, C.N., 1998. The elaboration of indices to assess biological water quality. A case study. Water Res. 32 (2), 380-392.

Harris, J.H., Silveira, R., 1999. Large-scale assessments of river health using index of Biotic Integrity with low-diversity fish communities. Freshwater Biol. 41, 235-252.
Hartwell, S.I. (Ed.), 1998. Biological Habitat Quality Indicators for Essential Fish Habitat, Workshop Proceedings, 14-15 July 1997, Charleston, SC. NOAA Technical Memorandum NMFS/SPO-32, NOAA/NMFS, Silver Spring, MD.

Hirsch, R.M., Alley, W.M., Wilber, W.G., 1988. Concepts for a National Water-Quality Assessment Program. Circular 1021, US Geological Survey, Reston, Virginia.

Holland, A.F., Shaughnessy, A., Hiegel, M.H., 1987. Long-term variation in mesohaline Chesapeake Bay macrobenthos: spatial and temporal patterns. Estuaries 10, 277-345.

Holland, A.F., Shaughnessy, A.T., Scott, L.C., Dickens, V.A., Ranasinghe, J.A., Summers, J.K., 1988. Progress report: long-term benthic monitoring and assessment program for the Maryland portion of Chesapeake Bay (July 1986-October 1987). PPRP-LTB/EST-88-1. Prepared for Maryland Power Plant Research Program and Maryland Department of the Environment, Office of Environmental Programs. Versar, Inc., ESM Operations, Columbia, MD.

Intergovernmental Task Force on Monitoring Water Quality ITFM, 1992. Ambient water-quality monitoring in the United States. US Geological Survey, Reston, Virginian.

Intergovernmental Task Force on Monitoring Water Quality ITFM, 1995. Final Report of the Intergovernmental Task Force on Monitoring Water Quality. Open-File Report 95-742, US Geological Survey, Reston, Virginia.

Jackson, L.E., Kurtz, J.C., Fisher, W.S. (Eds.), 2000. Evaluation Guidelines for Ecological Indicators. EPA/620/R-99/005. US Environmental Protection Agency, Office of Research and Development, Research Triangle Park, NC.

Jewett, S.C., Foder, H.M., Blanchard, A., 1999. Assessment of the benthic environment following oshore placer gold mining in the northeastern Bering Sea. Marine Environ. Res. 48, 90-122.

Karr, J.R., 1981. Biological integrity: a long-neglected aspect of water resource management. Ecol. Appl. 1, 66-84.

Karr, J., Chu, E., 1999. Restoring Life in Running Waters, Better Biological Monitoring. Island Press, Washington, DC.

Kerans, B.L., Karr, J.R., 1994. A benthic index of biotic integrity (B-IBI) for rivers of the Tennessee Valley. Ecol. Appl. 4, 768-785.

Leynen, M., Van den Berckt, T., Aerts, J.M., Cotelion, B., Berckmans, D., Ollivier, V., 1999. The use of Tubificidae in a biological early warning system. Environ. Poll. 105, 151-154.

Long, E.R., MacDonald, D.D., Smith, S.L., Calder, F.D., 1995. Incidence of adverse biological effects within ranges of chemical concentrations in marine and estuarine sediments. Environ. Manage. 19 (1), 81-97.

Manly, B.F.J., 1997. Randomization, Bootstrap and Monte Carlo Methods in Biology. Chapman \& Hall, New York.

Messer, J.J., Linthurst, R.A., Overton, W.S., 1991. An EPA program for monitoring ecological status and trends. Environ. Monitoring Assessment 17, 67-78.

National Research Council (NRC), 1990. Managing Troubled Waters: The Role of Marine Environmental Monitoring. National Academy Press, Washington, DC.

Nelson, W.G., Bergen, B.J., Benyi, S.J., Morrison, G., Voyer, R.A., Strobel, C.J., Rego, S., Thursby, G., Pesch, C.E., 1996. New Bedford Harbor Long-Term Monitoring Assessment Report: 
Baseline Sampling. EPA/600/R-96/097. US Environmental Protection Agency, National Health and Environmental Effects Research Laboratory, Atlantic Ecology Division, Narragansett, RI.

Nixon, S.W., Hunt, C.D., Nowicki, B.L., 1986. The retention of nutrients $(\mathrm{C}, \mathrm{N}, \mathrm{P})$, heavy metals $(\mathrm{Mn}, \mathrm{Cd}, \mathrm{Pb}, \mathrm{Cu})$, and petroleum hydrocarbons in Narragansett Bay. In: Lasserre, P., Martin, J.M. (Eds.), Biogeochemical Processes at the Land-Sea Boundary, Elsevier, New York, pp. 99-122.

O'Connor, S.J., Heasman, M.P., O'Connor, W.A., 1999. Evaluation of alternative suspended culture methods for the commercial scallop, Pecten fumatus Reeve. Aquaculture 171, 237-250.

Paul, J.F., Gentile, J.H., Scott, K.J., Schimmel, S.C., Campbell, D.E., Latimer, R.W., 1999. EMAP-Virginian Province 4-Year Assessment (1990-1993). EPA/620/R-99-004, US Environmental Protection Agency, Office of Research and Development, Narragansett, RI.

Pearson, T.H., Rosenberg, R., 1978. Macrobenthic succession in relation to organic enrichment and pollution of the marine environment. Oceanogr. Marine Biol. Ann. Rev. 16, 229-311.

Ranasinghe, J.A., Scott, L.C., Kelley, F.S., 1998a. Chesapeake Bay Water Quality Monitoring Program. Long-Term Benthic Monitoring and Assessment Component. Level 1 Comprehensive Report. July 1984-December 1997. Versar, Inc., Columbia, MD.

Ranasinghe, J.A., Scott, L., Frithsen, J.B., 1998b. MAIA Estuarine Benthic Index Comparison and Integration Workshop, 24 October 1997: Workshop Summary. Report prepared by Versar, Inc., Columbia, MD.

Reible, D.D., Popov, V., Valsaraj, K.T., Thibodeaux, L.J., Lin, F., Dikshit, M., Todaro, M.A., Fleeger, J.W., 1996. Contaminant fluxes from sediment due to Tubificid Oligochaete bioturbation. Water Res. 30 (3), 704-714.

Rhoads, D.C., McCall, P.L., Yingst, J.Y., 1978. Disturbance and production on the estuarine sea floor. Am. Scientist 66, $577-586$.

Sanders, H.L., 1956. Oceanography of Long Island Sound, 1952-1954 X: the biology of marine bottom communities. Bull. Bingham Oceanogr. Collect. 15, 345-414.

Sanders, H.L., 1960. Benthic studies in Buzzards Bay. III. The structure of the soft bottom community. Limnol. Oceanogr. 5, 138-153.

Sanders, H.L., Grassle, J.F., Hampson, G.R., Morse, L.S., Garner-Price, S., Jones, C.C., 1980. Anatomy of an oil spill: long-term effects from the grounding of the barge Florida off West Falmouth, Massachusetts. J. Marine Res. 38, 265-380.

SAS, 1990. SAS/STAT User Guide, Version 6, 4th Edition, Vol. 2. SAS Institute, Cary, NC.

Schimmel, S.C., Melzian, B.D., Campbell, D.E., Benyi, S.J., Rosen, J.S., Buffum, H.W., 1994. Statistical Summary: EMAP-Estuaries Virginian Province, 1991. EPA/620/R-94/005.
US Environmental Protection Agency, Office of Research and Development, Environmental Research Laboratory, Narragansett, Rhode Island.

Schubel, J.R., Carter, H.H., 1984. The estuary as a filter for fine-grained suspended sediment. In: Kennedy, V.S. (Ed.), The Estuary as a Filter. Academic Press, Orlando, FL, pp 81-104.

Science Advisory Board SAB, 1988. Future Risk: Research Strategies for the 1990s. The Report of the Research Strategies Committee. US Environmental Protection Agency, Science Advisory Board, Washington, DC.

Strobel, C.J., Valente, R.M., 1995. Quality Assurance Report: EMAP-Virginian Province, 1990-1993. EPA/620/R-95/007. US Environmental Protection Agency, Office of Research and Development, National Health and Environmental Effects Research Laboratory, Atlantic Ecology Division, Narragansett, RI.

Strobel, C.J., Buffum, H.W., Benyi, S.J., Petrocelli, E.A., Reifsteck, D.R., Keith, D.J., 1995. Statistical Summary: EMAP-Estuaries Virginian Province, 1990-1993. EPA/620/R-94/026. US Environmental Protection Agency, Office of Research and Development, National Health and Environmental Effects Research Laboratory, Atlantic Ecology Division, Narragansett, RI.

Strobel, C.J., Buffum, H.W., Benyi, S.J., Paul, J.F., 1999. Environmental monitoring and assessment program: current status of Virginian Province (US) estuaries. Environ. Monitoring Assessment 56, 1-25.

U.S. EPA, 1994. Methods for assessing the toxicity of sediment-associated contaminants with estuarine and marine amphipods. EPA 600/R-94/025. US Environmental Protection Agency, Office of Research and Development, Narragansett, RI.

U.S. EPA, 1995. EMAP-Estuaries Laboratory Methods Manual, Vol. I-Biological and Physical Analyses. EPA/620/R-95/008. US Environmental Protection Agency, Office of Research and Development, National Health and Environmental Effects Research Laboratory, Atlantic Ecology Division, Narragansett, RI.

Venables, W.N., Ripley, B.D., 1997. Modern Applied Statistics with S-Plus. Springer, New York.

Washington, H.G., 1984. Diversity, biotic and similarity indices, a review with special relevance to aquatic ecosystems. Water Resources 19 (6), 653-694.

Weisberg, S.B., Frithsen, J.B., Holland, A.F., Paul, J.F., Scott, K.J., Summers, J.K., Wilson, H.T., Heimbuch, D.G., Gerritsen, J., Schimmel, S.C., Latimer, R.W., 1993. Virginian Province Demonstration Project Report, EMAP-Estuaries, 1990. EPA/620/R-93/006. US Environmental Protection Agency, Office of Research and Development, Washington, DC.

Weisberg, S.B., Ranasinghe, J.A., Dauer, D.M., Schaffner, L.C., Diaz, R.J., Frithsen, J.B., 1997. An estuarine benthic index of biotic integrity (B-IBI) for Chesapeake Bay. Estuaries 20 (1), 149-158. 